\title{
Effects of High Temperature on the Residual Performance of Portland Cement Concretes
}

\author{
Evandro Tolentino ${ }^{\mathrm{a}}$, Fernando S. Lameiras ${ }^{\mathrm{a}}$, Abdias M. Gomes ${ }^{\mathrm{b}}$, \\ Cláudio A. Rigo da Silva ${ }^{\mathrm{b}}$ and Wander L. Vasconcelos ${ }^{\mathrm{c}_{*}}$ \\ ${ }^{a}$ Nuclear Energy Research Center (CDTN/CNEN), Belo Horizonte - MG, Brazil \\ ${ }^{\mathrm{b}}$ Dept of Materials Engineering and Construction, \\ Federal University of Minas Gerais (UFMG), Belo Horizonte - MG, Brazil \\ ${ }^{\mathrm{c}}$ Dept of Metallurgical and Materials Engineering, \\ Federal University of Minas Gerais (UFMG), Belo Horizonte - MG, Brazil
}

Received: September 27, 2001; Revised: July 10, 2002

\begin{abstract}
In this work we analyzed the "residual" performance of Portland cement concretes heat-treated at $600{ }^{\circ} \mathrm{C}$ after cooling down to room temperature. Concretes with characteristic compressive strength at 28 days of $45 \mathrm{MPa}$ and of $60 \mathrm{MPa}$ were studied. The heat-treatment was carried out without any imposed load. We measured the residual compressive strength and modulus of elasticity. The geometry of the structure was described by mercury intrusion porosimetry and nitrogen sorption tests. We observed a decrease of residual compressive strength and modulus of elasticity, with the raise of heat-treatment temperature, as a result of heat-induced material degradation. The results also indicated that the microstructural damage increased steadily with increasing temperature. Based on the results of this experimental work we concluded that residual mechanical properties of concrete are dependent of their original non heat-treated values.
\end{abstract}

Keywords: mercury intrusion porosimetry, nitrogen sorption, residual mechanical property

\section{Introduction}

High-performance concrete is a construction material that has been used in increasing volumes lately. Concrete is made with appropriate materials combined according to a selected mix design and properly mixed, transported, placed, consolidated, and cured so that the resulting concrete will give excellent performance in the structure in which it will be placed, in the environment to which it will be exposed, and with the loads to which it will be subjected for its design life ${ }^{1}$. High-performance concrete goes beyond the limits of the normal performance range ${ }^{2}$.

In recent years, high-performance concretes have been produced based on a low water-cement ratio, cement paste containing both silica fume and superplasticizer, along with high-strength aggregates ${ }^{3}$. As regards high-performance concrete features, they include early stripping, greater stiffness (which provides increased girder spacing, shallower members, and longer spans), increased durability, and enhanced mechanical properties ${ }^{4,5}$. In fact, high-performance concrete is the most economical way to resist axial load and it is economical purely on the basis of cost to resist a specified load, which allows the use of smaller columns ${ }^{4}$. The advantages of using high-strength concrete in multistory buildings are clearly known ${ }^{6}$.

In spite of the current increase in volume of high-performance concrete construction, high-performance concrete is the latest catch phrase in concrete. It has replaced the high-strength concrete cry of the 1980's boom. Some still think high-performance concrete is a new name for highstrength concrete, but it is much more ${ }^{2}$. Ultimately, highstrength concrete is one type of high-performance concrete.

Although high-performance concrete is often considered a relatively new material, its development has been gradual over many years, and, as the development continues, the definition of high-performance concrete has changed. In the 1950's, concrete with compressive strength of $34 \mathrm{MPa}$ was considered high-strength. Meanwhile, in

*e-mail:wlv@ demet.ufmg.br 
the 1960's concretes with $41 \mathrm{MPa}$ and $52 \mathrm{MPa}$ compressive strength were used commercially, and, in the early 1970's, $62 \mathrm{MPa}$ concrete was produced. More recently, compressive strengths approaching $138 \mathrm{MPa}$ have been used in cast-inplace buildings ${ }^{7}$.

It is well known that the safety and serviceability of the concrete structures cannot be realized without a comprehensive knowledge of the material's fundamental properties. Concerns have been raised lately about the statement that the stronger the concrete, the more durable it would be under severe environmental conditions. Concrete durability and deterioration are so closely related that they must be considered together. In fact, durability is the main criterion in assessing concrete deterioration ${ }^{8}$. Since the permeability of high-strength concrete mixtures is sufficiently low, the use of high-strength mixtures has been extended to aggressive environments, where durability is a prime consideration. Nevertheless, since high-strength does not necessarily mean low permeability in service, this issue has attracted some attention recently9.

Furthermore, while high-performance concrete outperforms conventional concrete in nearly every performance category, one Achilles heel is its performance when exposed to fire ${ }^{10}$. Fire is one of the most destructive accidental loads that a structure can be subjected to. In a typical fire, the temperature reaches $500{ }^{\circ} \mathrm{C}$ in about $10 \mathrm{~min}$ and $950{ }^{\circ} \mathrm{C}$ in $1 \mathrm{~h}$. During fires, temperatures as high as $900{ }^{\circ} \mathrm{C}$ are common but only the outer layers of concrete members become drastically hot, while the inner layers remain cooler ${ }^{11}$. Moreover, the residual compressive strength of the concrete, when cold after heating to various temperatures, is important in connection with the repair of a structure after a fire ${ }^{12}$.

With regard to residual properties of concretes, they are extremely relevant, when special structures such as the secondary-containment shells of nuclear reactors or coal-gasification vessels are at issue, where heavy loads have to be carried even after the exposure to high temperatures, whether by accident or not. Unfortunately, scanty information is available on thermo-hygral and thermal-mechanical properties of high-strength concrete ${ }^{13}$. Such information is critical to the design and construction of safe and durable structures ${ }^{10}$.

The present paper summarizes information on residual mechanical properties and microstructure of thermally damaged normal strength and high-strength Portland cement concretes. The significance of this paper is threefold: (1) to present information about the residual mechanical properties of high-strength concretes, thereby supplementing the small amount of existing information; (2) to present information about the effects of transient high temperatures on the pore structure of high-strength concrete; and (3) to compare the actions in residual mechanical properties at room temperature, after submitted to $600{ }^{\circ} \mathrm{C}$, of high-strength concrete to those of normal strength concrete. The test program consisted of preparing two concrete compositions and documenting the compressive strength, modulus of elasticity, and pore structure.

\section{Experimental}

\subsection{Materials}

The mix designs used in the test program had characteristic compressive strength $\left(\mathrm{f}_{\mathrm{ck}}\right)$ at 28 days of $45 \mathrm{MPa}$ and $60 \mathrm{MPa}$, referred to herein as normal strength concrete and high-strength concrete, respectively, and shortened to NSC and HSC. The test specimens consisted of $100 \times 200 \mathrm{~mm}$ concrete cylinders, which were cast according to NBR-5738 Brazilian Standard Test Method ${ }^{14}$. The materials used in NSC and HSC were: tap water, $9.5 \mathrm{~mm}$ maximum size basalt as the coarse aggregate, river sand as the fine aggregate, and sulfonated melamine superplasticizer as water-reducing admixture. A commercially available Brazilian CP II-E-32 - ASTM Type I (SM) - Portland cement was used in the NSC. A commercially available Brazilian CP V ARI PLUS - ASTM Type III - Portland cement was used in the HSC. Eleven percent of the cement was replaced by silica fume in the HSC. Table 1 presents the concrete mix proportions. Twenty-four hours after casting, the specimens were demolded, and they were placed in a moist-curing room $\left(25^{\circ} \mathrm{C}, 65 \%\right.$ R.H.) prior to further testing.

\subsection{Heat-treatments}

In accordance with RILEM's recommendations ${ }^{15-16}$, two types of conditions are commonly used to study the effect of high temperature on the properties of concrete, namely, service conditions and accident conditions. Service conditions ${ }^{15-16}$ normally cover test temperatures in the range of 20-200 ${ }^{\circ} \mathrm{C}$ and moisture states between the boundary condition ' $d$ ' - drying (unsealed) concrete - and the boundary condition 'nd' - moisture saturated (sealed) concrete. In

Table 1. Concrete mix proportions.

\begin{tabular}{lcc}
\hline Materials & NSC & HSC \\
\hline Cement $\left(\mathrm{kg} / \mathrm{m}^{3}\right)$ & 460 & 540 \\
Natural sand $\left(\mathrm{kg} / \mathrm{m}^{3}\right)$ & 648.1 & 670.6 \\
Coarse aggregate $\left(\mathrm{kg} / \mathrm{m}^{3}\right)$ & 1180.4 & 1563.4 \\
Superplasticizer $\left(\mathrm{kg} / \mathrm{m}^{3}\right)$ & 2.3 & 5.1 \\
Water $\left(\mathrm{kg} / \mathrm{m}^{3}\right)$ & 193.3 & 169.8 \\
Silica fume $\left(\mathrm{kg} / \mathrm{m}^{3}\right)$ & - & 61 \\
w/c rate & 0.42 & - \\
w/(c + sf) rate & - & 0.28 \\
Slump (mm) & 7.5 & 4.5 \\
Proportion (by weight) & $1: 1.407: 2.567$ & $1: 1.243: 2.898$ \\
\hline
\end{tabular}


general, boundary condition 'd' applies to drying structures in air with a maximum thickness smaller than $400 \mathrm{~mm}$, or structures with no point that is further away than $200 \mathrm{~mm}$ from a surface exposed to air. Boundary condition 'nd' is defined for sealed structures independent of their dimensions, for zones of structures with a distance greater than $200 \mathrm{~mm}$ from the surface exposed to air, or structures under water. The recommended heating rate for service conditions is $0.1{ }^{\circ} \mathrm{C} / \mathrm{min}$. Accident conditions ${ }^{15-16}$ normally cover temperatures in the range of $20-750{ }^{\circ} \mathrm{C}$ or above and transient moisture states, i.e., the test specimens are unsealed and allowed to dry during heating. In this case the moisture boundary condition is the same as condition ' $\mathrm{d}$ '. The recommended heating rate for accident conditions is $0.5^{\circ} \mathrm{C} / \mathrm{min}$. Therefore, in order to study the effects of a single high-temperature cycle, after cooling down to room temperature, we subjected the cylindrical specimens to heat treatment at $600{ }^{\circ} \mathrm{C}$, representing accidental conditions. The heating device used was an open to air electric furnace. The heating and cooling rate used for the tests were $50{ }^{\circ} \mathrm{C} / \mathrm{h}$ and $10{ }^{\circ} \mathrm{C} / \mathrm{h}$, respectively. The maximum test temperature was maintained for a period of $2 \mathrm{~h}$ in order to homogenize the temperature field of the specimen. The cooling process of the furnace was controlled down to $200{ }^{\circ} \mathrm{C}$ and then the specimens reached the room temperature by natural cooling within the closed furnace, in order to avoid significant cracking due to thermal stresses or significant moisture pick up. Two cylindrical specimens were tested at $600{ }^{\circ} \mathrm{C}$, which were unloaded during tempering, and two reference specimens were left non heat-treated as controls. After heattreated the specimens were left to rest for 6 to 8 weeks in a controlled environment of $25^{\circ} \mathrm{C}$ and $65 \%$ R.H., before being tested, in order to reach the minimum strength situation $\left(\right.$ Rilem $\left.^{17}\right)$.

\subsection{Compressive Strength}

The uniaxial compressive strength tests were carried out in accordance with the procedure proposed in the NBR5739 Brazilian test method ${ }^{18}$. The non heat-treated concrete specimens had their compressive strengths measured at 28 days after casting and the heat-treated concrete specimens had their strengths obtained after resting for 6 to 8 weeks in a controlled environment $\left(25^{\circ} \mathrm{C}\right.$ and $65 \%$ R.H.). Two specimens were tested for each combination of test parameters (mix proportion and heat-treatment) and the bigger of the test values was taken as compressive strength.

\subsection{Modulus of Elasticity}

We used the testing by ultrasonic pulse velocity measurements in order to determine the modulus of elasticity. The tests were carried out using a portable ultrasonic nondestructive digital-indicating tester PUNDIT Mk V, with flat transducers (nominal frequency of $99 \mathrm{kHz}$ and diameter of
$25 \mathrm{~mm})$. The tests were performed in accordance with NBR8802 Brazilian test method ${ }^{19}$. The cylindrical specimens were tested at ambient conditions ( $25^{\circ} \mathrm{C}$ and $65 \%$ R.H.).

\subsection{Mercury Intrusion Porosimetry}

We used an AutoPore III 9420 (Micromeritics) porosimeter in order to do the mercury intrusion porosimetry tests. This equipment is able to produce pressures up to $414 \mathrm{MPa}$ and to cover pore diameters in the range $0.005 \mu \mathrm{m}$ to $360 \mu \mathrm{m}$. We assumed mercury density, surface tension, and contact angle values of $13.5335 \mathrm{~cm}^{3} / \mathrm{g}, 485 \mathrm{dyn} / \mathrm{cm}$ and $140.5^{\circ}$, respectively. The sample in small pieces (with aggregates removed), taken from near the surface of the cylindrical specimens, were dried for $24 \mathrm{~h}$ in an oven at $100{ }^{\circ} \mathrm{C}$ before testing. We used penetrometers of $6.0642 \mathrm{~cm}^{3}$ and $16.2440 \mathrm{~cm}^{3}$ in volume. The size of the samples ranged from $4 \mathrm{~g}$ to $5 \mathrm{~g}$, for penetrometers of $6.0642 \mathrm{~cm}^{3}$, and from $13 \mathrm{~g}$ to $15 \mathrm{~g}$, for penetrometers of $16.2440 \mathrm{~cm}^{3}$. The maximum stem volume used ranged from $25 \%$ to $90 \%$. The estimated values of standard deviation $(\sigma)$ for median pore diameter and total intrusion volume are $0.02 \mathrm{~mm}$ and $0.003 \mathrm{~cm}^{3} / \mathrm{g}$, respectively. The estimated values of coefficient of variation $(\mathrm{CV})$ for median pore diameter and total intrusion volume are $9.5 \%$, and $6.8 \%$, respectively.

\subsection{Nitrogen sorption}

The nitrogen sorption tests were conducted using an Autosorb 1 (Quantachrome Corporation) equipment. The samples were tested in powder shape and they were outgassed at $120^{\circ} \mathrm{C}$ for $12 \mathrm{~h}$. The sample mass ranged from $0.3 \mathrm{~g}$ to $0.7 \mathrm{~g}$. The analysis time ranged from $166 \mathrm{~min}$ to 429 min The estimated values of standard deviation $(\sigma)$ for median pore radii and total pore volume are $3 \mathrm{~nm}$ and $0.003 \mathrm{~cm}^{3} / \mathrm{g}$, respectively. The estimated values of coefficient of variation $(\mathrm{CV})$ for median pore radii and total pore volume are $12.5 \%$ and $11 \%$, respectively.

\section{Results and Discussion}

The results of residual compressive strength are given in Table 2. The test results showed a reduction in compressive strength with the raise of heat-treatment temperature, for the two concrete compositions studied. HSC showed a larger reduction in compressive strength due to exposure to high temperature than NSC. For the NSC, heat-treated at $600{ }^{\circ} \mathrm{C}$,

Table 2. Residual compressive strength.

\begin{tabular}{lcc}
\hline & \multicolumn{2}{c}{ Residual compressive strength (MPa) } \\
& NSC & HSC \\
\hline Non heat-treated & 52 & 64 \\
$600{ }^{\circ} \mathrm{C}$ & 22 & 20 \\
\hline
\end{tabular}


only 42 percent of the non heat-treated strength is left while the same for the HSC was of the order of 31 percent.

The results of residual modulus of elasticity determined from tests are given in Table 3. The standard deviation and the confidence interval of the population mean are also presented. The $n-1$ degrees of freedom of all tests were 3 . The test results showed a reduction in modulus of elasticity with the raise of heat-treatment temperature, for both the NSC and HSC studied. The loss of modulus of elasticity resulting from exposure to high temperature was smaller for NSC compared to that suffered by the HSC. For the NSC, heattreated at $600{ }^{\circ} \mathrm{C}$, only 51 percent of the non heat-treated modulus of elasticity is left while the same for the HSC was of the order of 41 percent.

As is well known, at the macroscopic level, ordinary Portland cement concrete is a composite material, consisting of discrete aggregates dispersed in a continuous cementpaste matrix. As with other composites, the bonding region or transition zone in concrete between matrix and aggregate is a critical component of mechanical performance. Moreover, the microstructure in the transition zone is characterized by high porosity, composed of relatively large pores. One of the major effects of adding silica fume to concrete in order to obtain high-performance concretes is the modification of the transition zone ${ }^{20}$. The effect of silica fume on the total porosity of the pastes and the paste component of the concretes is similar and so changes to the porosity cannot account for the inherent strengthening effect observed in the silica fume concretes. This effect could be a result of the densification of the microstructure in the transition zone, which leads to an improved aggregate/paste matrix bond. As a result, the aggregate particles may become reinforcing inclusions, rather than mechanically inert fillers $^{21}$. Accordingly, the results of mechanical behavior of concretes, presented in Table 2, Table 3 and Fig. 1, evidence heat-induced nucleation, propagation, and joining of cracks inside the paste component of the concretes. Apparently, in HSC, the temperature dependent destruction of cement paste replaced a denser microstructure in the transition zone by a more cracked, and the bond failure in some of the contact zones between aggregates and matrix produced a significant non-linear elastic behavior. As regards temperature dependent destruction, its influence on the strength of HSC is higher than on NSC because the cement matrix in HSC must carry higher loads than in NSC.

In order to study the effect of transient high temperatures on the residual mechanical properties, we presented linear plots of residual modulus of elasticity, as percentage of their original non heat-treated modulus of elasticity $v s$. temperature - Fig. 1a - and residual modulus of elasticity, of concretes heat-treated at $600{ }^{\circ} \mathrm{C}$, as percentage of their original non heat-treated modulus of elasticity $v s . \mathrm{f}_{\mathrm{ck}}$ Fig. $1 \mathrm{~b}$.
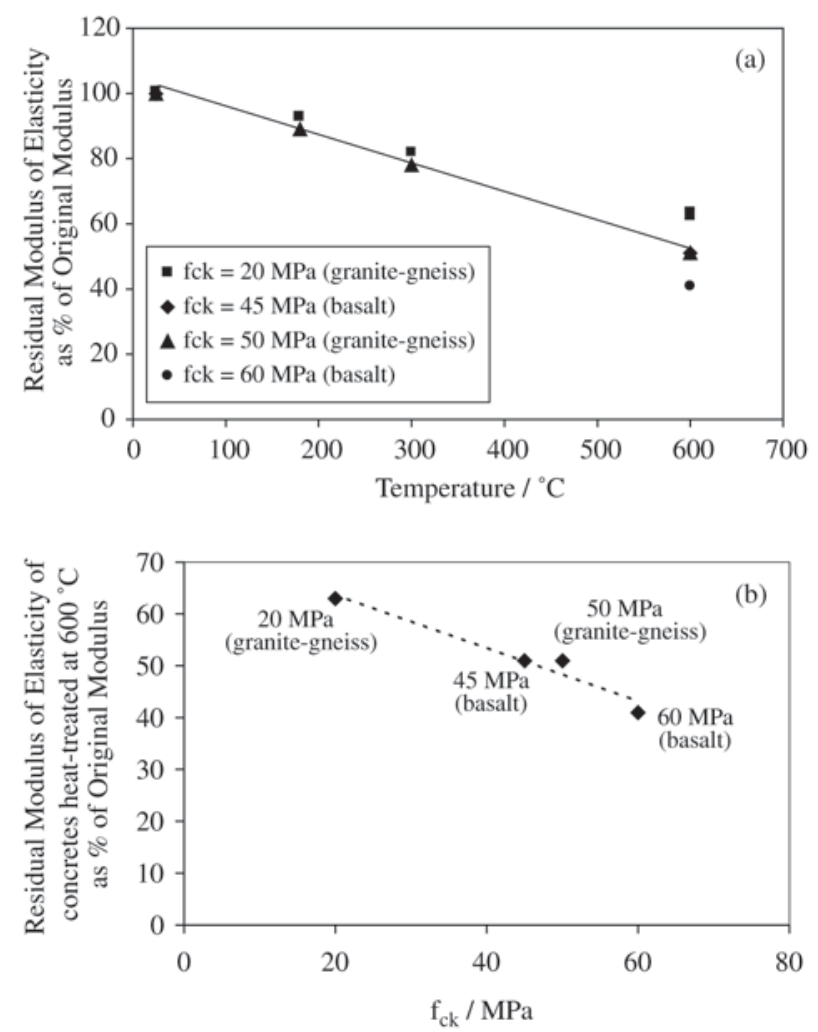

Figure 1. a) Residual modulus of elasticity as percentage of original non heat-treated modulus of elasticity $v s$. temperature, for basalt and granite- gneiss ${ }^{22}$ concretes; b) Residual modulus of elasticity of concretes heat-treated at $600{ }^{\circ} \mathrm{C}$ as percentage of original non heat-treated modulus of elasticity $v s . \mathrm{f}_{\mathrm{ck}}$, for basalt and granite-gneiss ${ }^{22}$ concretes.

Table 3. Residual modulus of elasticity.

\begin{tabular}{lcc}
\hline & \multicolumn{2}{c}{ Residual modulus of elasticity (GPa) } \\
& NSC & HSC \\
\hline Non heat-treated & $\overline{\mathrm{x}}=34.1$ & $\overline{\mathrm{x}}=34.4$ \\
& $\sigma=0$ & $\sigma=0.5$ \\
& 34.1 & $34.4 \pm 0.9$ \\
\hline $600{ }^{\circ} \mathrm{C}$ & $\overline{\mathrm{x}}=17.4$ & $\overline{\mathrm{x}}=14.0$ \\
& $\sigma=1.0$ & $\sigma=2.2$ \\
& $17.4 \pm 1.8$ & $14.0 \pm 4.0$ \\
\hline
\end{tabular}

Granite-gneiss concrete data from Tolentino ${ }^{22}$ were included in this analysis. Both Fig. 1a and Fig. 1b show a good linear correlation between residual modulus of elasticity and heattreatment temperature - correlation coefficients $(\mathrm{r})$ are 0.972 and 0.974 , respectively. The slope of the line presented on Fig. $1 \mathrm{~b}$ is dependent of characteristic compressive strength 
of concrete. Based on Fig. 1b data and knowing that compressive strength and modulus of elasticity are close related, one can observe that residual mechanical properties of concretes are dependent of their original non heattreated values.

Figure 2 and Fig. 3 show for NSC and HSC the intruded $\mathrm{Hg}$ volume $v s$. pore diameter curves and incremental intrusion $v s$. pore diameter curves obtained, respectively, from mercury intrusion porosimetry tests of non heat-treated concrete specimens and heat-treated at $600{ }^{\circ} \mathrm{C}$. From the results of mercury intrusion porosimetry, obtained for non heat-treated concretes, presented in Fig. 2, it appears that both NSC and HSC curves are convex to the pressure axis. Another important aspect is that the pore structure of HSC shows a coarser family of pores. It can be seen that the poresize distribution results of HSC are not monomodals in essence, with several maxima appearing in the distribution functions, corresponding to mesopores (pores with radii between $0.002 \mu \mathrm{m}$ and $0.05 \mu \mathrm{m}$ ) and macropores (pores with openings exceeding $0.05 \mu \mathrm{m}$ in radius). This phenomenon can be attributed to the high dosage of water-reducer (superplasticizer) used for making the $\mathrm{HSC}^{23}$. The pore-size distribution presented in Fig. 3 show that the heat-induced concrete degradation develops a coarser pore structure in
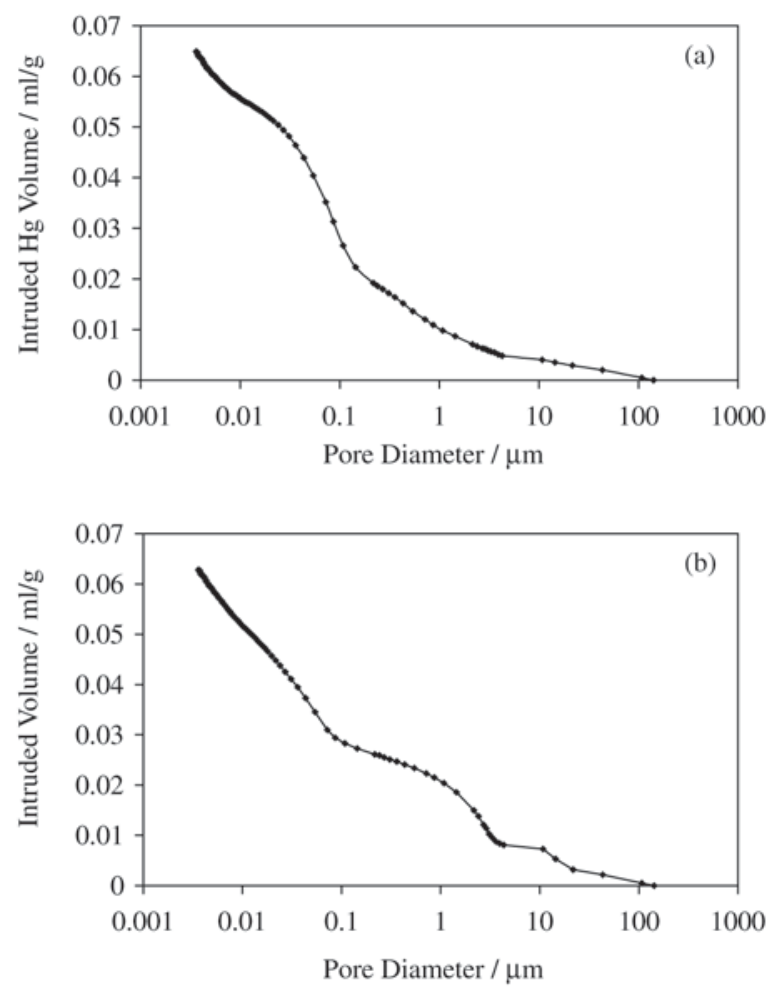

HSC than that of NSC. Much of the additional pore volume of HSC are in the macroporosity region. While the NSC pore-size distribution curve is still convex to the pressure axis, the HSC pore-size distribution curve is concave.

Figure 4 presents the adsorbed $\mathrm{N}_{2}$ volume $v s$. relative pressure $\mathrm{P} / \mathrm{P}_{0}$ curves. The results of specific volume of pores measured by nitrogen sorption tests are given in Table 4 . The results indicate a decreasing tendency of specific volume of pores with the raise of heat-treatment temperature. It is believed that with increasing the heat-treatment temperature the gel porosity (pores with openings not exceeding $0.01 \mu \mathrm{m}$ in diameter) reduces and shifts to larger radii, leaving the measuring capacity of the nitrogen sorption method.

Table 4. Specific volume of pores measured by nitrogen sorption tests.

\begin{tabular}{lcc}
\hline & \multicolumn{2}{c}{ Specific volume of pores $\left(\mathrm{cm}^{3} / \mathrm{g}\right)$} \\
\hline & NSC & HSC \\
Non heat-treated & 0.037 & 0.024 \\
$600{ }^{\circ} \mathrm{C}$ & 0.022 & 0.012 \\
\hline
\end{tabular}
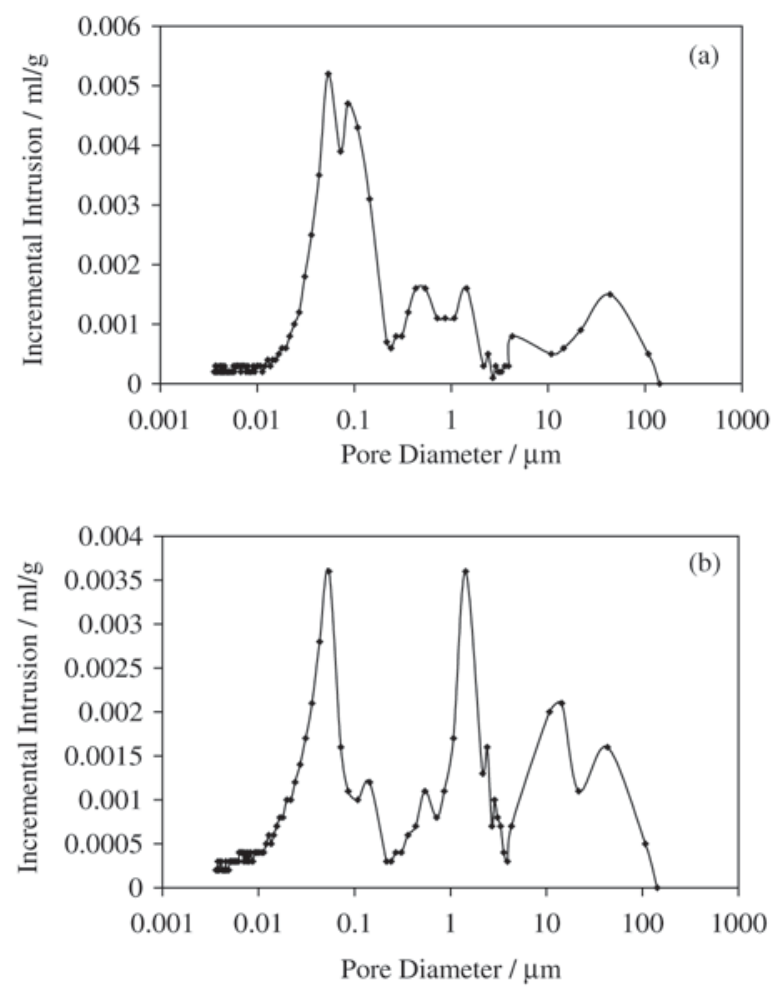

Figure 2. Intruded $\mathrm{Hg}$ volume $v s$. pore diameter curves and incremental intrusion vs. pore diameter curves, obtained from mercury intrusion porosimetry tests of non heat-treated reference concrete specimens: a) NSC; b) HSC. 

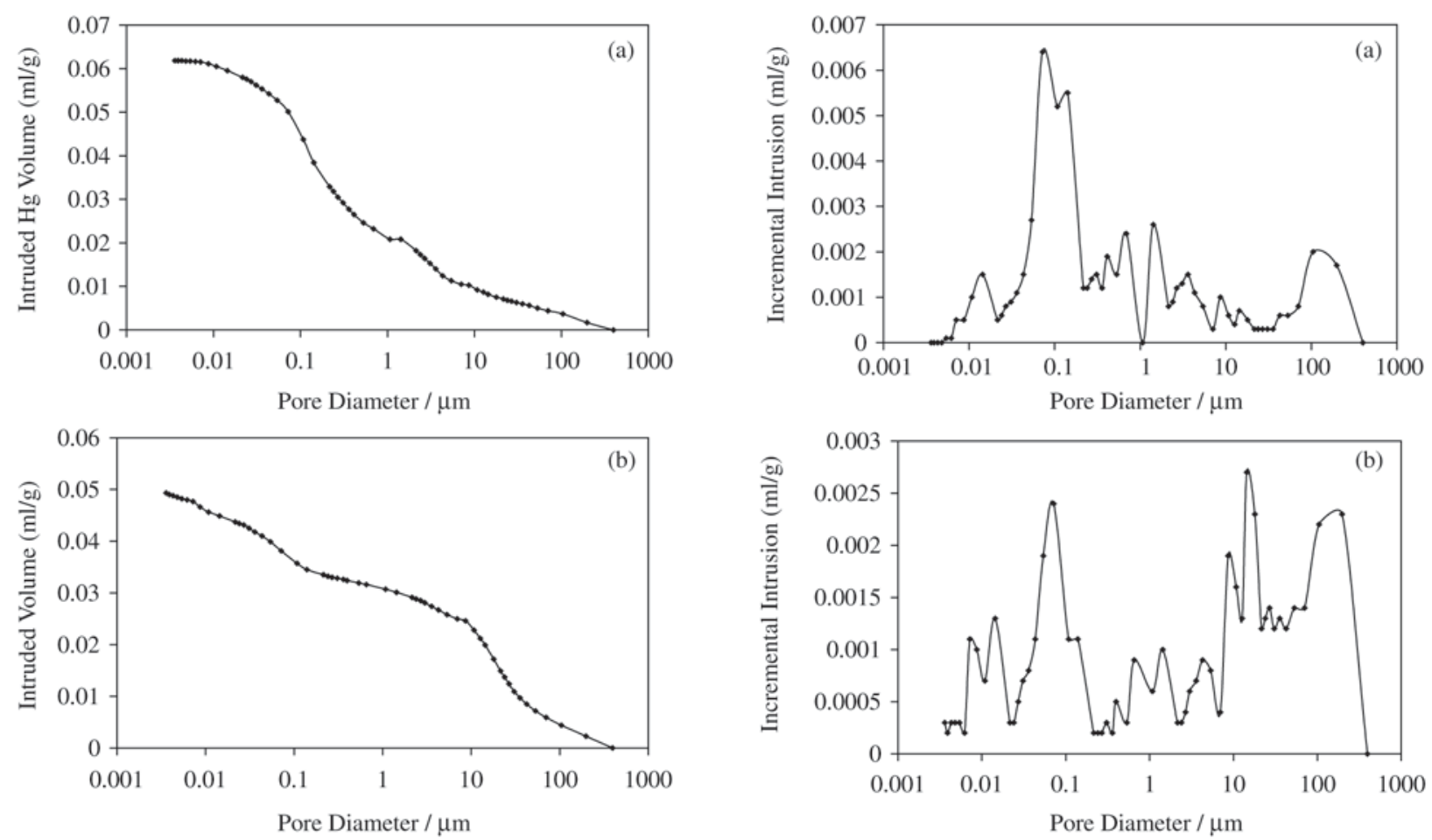

Figure 3. Intruded $\mathrm{Hg}$ volume vs. pore diameter curves and incremental intrusion vs. pore diameter curves, obtained from mercury intrusion porosimetry tests of concrete specimens heat-treated at $600{ }^{\circ} \mathrm{C}$ : a) NSC; b) HSC.
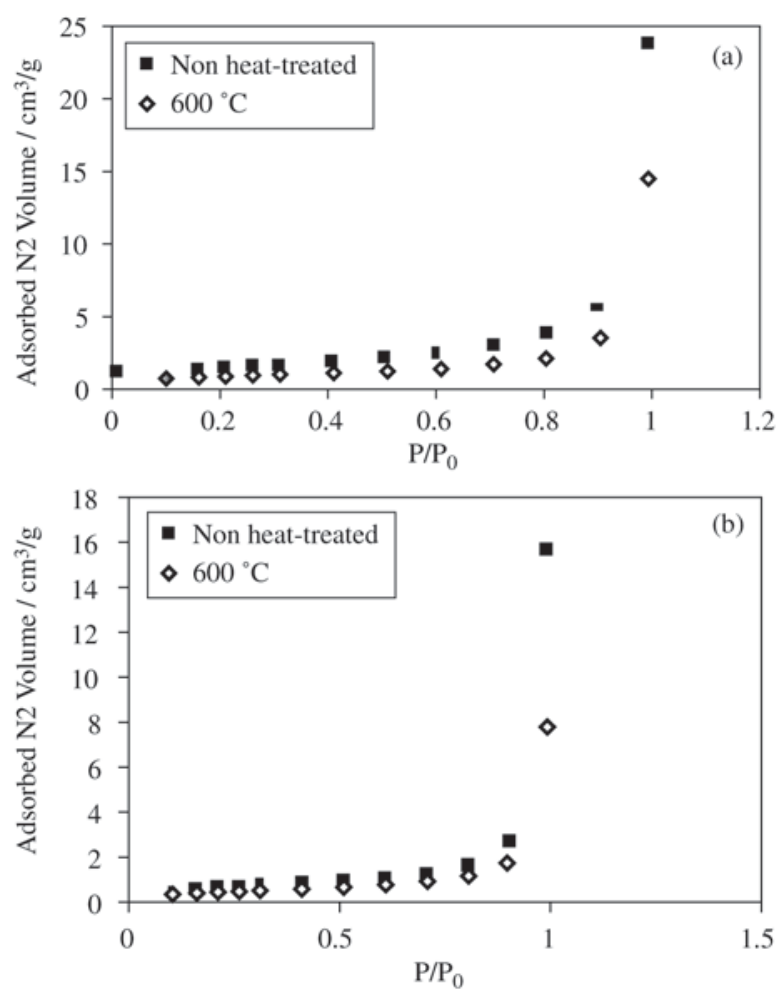

Figure 4. Adsorbed $\mathrm{N}_{2}$ volume vs. relative pressure $\mathrm{P} / \mathrm{P}_{0}$ : a) $\mathrm{NSC}$; b) HSC.

\section{Conclusion}

Residual compressive strength and modulus of elasticity, measured at room temperature, are very sensitive measures of the change in the structure of thermally damaged concrete. Mercury intrusion porosimetry and nitrogen sorption results revealed that coarser microstructure is produced as result of high temperature. The results of this study suggest the dependence of residual mechanical properties with their original non heat-treated values.

\section{Acknowledgements}

The authors wish to thank CNPq (Brazilian Research Agency), CAPES (Brazilian Agency for Graduate Programs) and FAPEMIG (Research Agency of the State of Minas Gerais) for providing the financial support for this investigation. The authors would also like to express their thanks to Dr. A. Valadão Cardoso of CETEC (Technology Center of Minas Gerais) for his assistance with mercury intrusion porosimetry tests. Contribution from the technical staff of the Laboratory of Concrete of the Department of Civil Engineering of FUMEC University is gratefully acknowledged, particularly Professor R. J. Pedrosa Reis for his valuable guidance and advice. 


\section{References}

1. Forster, S.W. Concrete International, Detroit, v. 16, n. 10, p. 33-4, Oct. 1994.

2. Papworth, F.; Ratcliffe, R. Concrete International, Detroit, v. 16, n. 10, p. 39-44, Oct. 1994.

3. Bentz, D.P.; Garboczi, E.J. ACI Materials Journal, Detroit, v. 88, n. 5, p. 518-29, Sept.-Oct. 1991.

4. Webb, J. Concrete International, Detroit, p. 27-32, Jan. 1993

5. Russel, H.G. Concrete International, Detroit, v. 19, n. 8 , p. 62-3, Aug. 1997.

6. Hwee, Y.S., Rangan, B.V. ACI Materials Journal, Detroit, v. 87, n. 5, p. 440-5, Sept.-Oct. 1990.

7. American Concrete Institute, ACI Committee 363, Stateof-the-art report on high-strength concrete, ACI 363R92. ACI Journal, Detroit, 1992. 55 p.

8. Sarkar, S.L.; Beaulieu, J. Cement and Concrete Research, [s.1.], v. 23, n. 4, p. 874-84, 1993.

9. Mehta, P.K. Concrete International, Detroit, p. 27-33, July 1997.

10. Bentz, D.P. ACI Materials Journal, Detroit, v. 97, n. 3 , p. 351-9, May-June 2000.

11. Nassif, A.Y.; Burley, E.; Rigden, S. Magazine of Concrete Research, London, v. 47, n. 172, p. 271-8, Sept. 1995.

12. Malhotra, H.L. Magazine of Concrete Research, London, v. 8, n. 23, p. 85-94, Aug. 1956.

13. Felicetti, R.; Gambarova, P.G. ACI Materials Journal, Detroit, v. 95, n. 4, p. 395-406, July-Aug. 1998.

14. Associação Brasileira de Normas Técnicas. NBR-5738, Moldagem e Cura de Corpos-de-Prova Cilíndricos ou Prismáticos de Concreto, 1994. ABNT, Rio de Janeiro, 1994. 9 p.
15. Rilem Draft Recommendation 129-MHT: Test Methods for Mechanical Properties of Concrete at High Temperatures. Compressive strength for service and accident conditions. Materials and Structures, [s.1.], v. 28, p. 410-14, 1995.

16. Rilem TC 129-MHT: Test Methods for Mechanical Properties of Concrete at High Temperatures, Recommendations: Part 7: Transient Creep for service and accident conditions. Materials and Structures, [s.1.], v. 31, p. 290-95, June1998.

17. Rilem-Committee 44-PHT: Behavior of concrete at high temperatures. Edited by U. Schneider, Dept of Civil Engineering, Gesamthochschule, Kassel University, Kassel (Germany), 1985, 122 p.

18. Associação Brasileira de Normas Técnicas. NBR-5739, Ensaio de Compressão de Corpos-de-Prova Cilíndricos de Concreto, 1980. ABNT, Rio de Janeiro, 1980

19. Associação Brasileira de Normas Técnicas. NBR-8802, Determinação da Velocidade de Propagação de Onda Ultra-Sônica, 1985. ABNT, Rio de Janeiro, 1985. 8 p.

20. Bentz, D.P.; Garboczi, E.J. ACI Materials Journal, Detroit, v. 88, n. 5, p. 518-29, Sept.-Oct. 1991.

21. Scrivener, K.L.; Bentur, A.; Pratt, P.L. Advances in Cement Research, London, v. 1, n. 4, p. 230-7, Oct. 1988.

22. Tolentino, E. Desenvolvimento e aplicação de uma metodologia para a avaliação do desempenho térmico de concretos de cimento Portland. Belo Horizonte, UFMG, 2000. 316 p. Tese (Doutorado em Engenharia Metalúrgica e de Materiais) - Escola de Engenharia, Universidade Federal de Minas Gerais, 2000.

23. Sarkar, S.L.; Aïtcin, P.C. Cement, Concrete and Aggregates, [s.1.], v. 9, n. 2, p.57-64, 1987. 